\title{
The Model Penal Code and the Sexual Conduct of Police Officers While on Duty
}

\author{
Donald Lee Buresh \\ Cybersecurity Assurance and Policy Department, Morgan State University, Baltimore, Maryland
}

Email address:

LoganSquareDon@sbcglobal.net

\section{To cite this article:}

Donald Lee Buresh. The Model Penal Code and the Sexual Conduct of Police Officers While on Duty. International Journal of Law and Society. Vol. 3, No. 4, 2020, pp. 204-208. doi: 10.11648/j.ijls.20200304.17

Received: August 13, 2020; Accepted: November 24, 2020; Published: December 11, 2020

\begin{abstract}
The purpose of this paper is to examine the penalties proposed in the Model Penal Code when a police officer engages in sexual conduct while on duty. At issue is whether the Model Penal Code should explicitly make it an enhanced penalty or offense when a law enforcement officer engages in sexual conduct while on duty with any individual, including a child, or is involved in sexual violence of any kind, whether on or off duty. The paper discusses the procedural due process issue, substantive due process issues, and equal protection issues of including an enhanced penalty when a police officer engages in sexual conduct with an individual involved in sexual violence. The work also considers the moral authority of the Model Penal Code as well as public welfare matters when a police officer participates in such behavior. The article concludes by recommending that the Model Penal Code should specifically make it an enhanced penalty or offense when a law enforcement officer engages in sexual conduct while on duty with any individual, including a child, or is involved in sexual violence of any kind, whether on or off duty. The conclusion seems appropriate given that police officers hold the public trust when performing their duties.
\end{abstract}

Keywords: Enhanced Criminal Penalties, Law Enforcement, Model Penal Code, Sexual Conduct

\section{The Model Penal Code}

After many years of attempting to formulate a uniform criminal code for the United States, on May 24, 1962, the American Law Institute adopted the Model Penal Code [1]. The current form of the MPC was last updated in 1981 [1]. As of 2007, only 37 states have adopted modified and partial versions of the Code [1]. Even so, New York, New Jersey, and Oregon have adopted nearly all of its provisions [2].

Section 213 of the Model Penal Code describes rape as sexual intercourse that is initiated by a man against a woman who is not his wife, where the man compels the woman by force or by the threat of death, serious bodily injury, extreme pain, or kidnapping, to be inflicted sexual intercourse. According to the MPC, such behavior constitutes a first-degree felony [3]. Section 213.3 deals with the criminal corruption of minors and seduction via deviate sexual intercourse, where the deviate sexual act consists of either oral or anal sexual intercourse [3]. In this case, a violation of Section 213.3 is a third-degree felony if the victim is less than 16 years old; otherwise, it is a misdemeanor. Finally, Section 213.4 is concerned with sexual assault, where the sexual act is vaginal sexual intercourse [3]. Although Section 213.4 lists a variety of situations where sexual assault may occur, the penalty for sexual assault is a misdemeanor [3].

The problem with the Model Penal Code is that the current definitions of rape and sexual assault are simply inadequate [4]. These sections of the MPC do not address the situation where an individual of authority, such as a law enforcement officer, threatens an adult woman or a female minor child typically with imprisonment unless the victim agrees to engage in sexual intercourse with the law enforcement office [3].

In recent years, the American Law Institute has attempted to rectify this deficiency in the MPC. Still, as of this date, the ALI has yet to adopt any of the revisions of Section 213 of the MPC that have been submitted to the organization [5]. The reason that these changes to Section 213 have yet to be adopted is that the meaning of consent varies [5]. Therefore, this case presents a genuine need to significantly revise Section 213 so that police officers can no longer sexually 
exploit the individuals who they contact, whether they are adult men or women, or even minor children.

\section{Discussion of Issue}

The issue above will be analyzed in terms of procedural due process, substantive due process, equal protection, the moral authority of the MPC, and public welfare or public policy considerations. The analysis of these five possibilities may differ depending upon whether the victim is an adult or a minor child, or whether the law enforcement officer is on duty or off duty.

\section{Procedural Due Process Justifies Inclusion}

Here, the issue is whether procedural due process justifies the inclusion into the MPC of an enhanced penalty or offense when a law enforcement officer engages in sexual conduct while on duty with any individual, including a child, or is involved in sexual violence of any kind whether on or off duty. In the United States constitutional law, procedural due process is a legal doctrine that requires government officials to follow fair procedures before depriving a person of life, liberty, or property [6].

Procedural due process is concerned with depriving a person with a significant interest in life, liberty, property, or physical freedom [8]. When an individual is stopped by a law enforcement officer in the course of his or her duties for whatever reason, that individual may have his or her physical freedom curtailed at least for a relatively short period. The person may or may not be made aware of the reason for being stopped. The reason for the stop could be reasonable suspicion or probable cause [7, 8]. A person stopped by a law enforcement officer may not be aware that he or she need not consent to a search under the Fourth Amendment. The law enforcement officer may not correctly inform the individual of the reason for being stopped. The police officer may engage constitutionally protected low-level trickery to detain a person [9].

A government official, public official, or municipal officer is "[o]ne who holds or is invested with a public office; a person elected or appointed to carry out some portion of a government's sovereign powers" [10]. A public officer is similarly defined. In June 2008, Illinois added sworn law enforcement or peace officers to their definition of public officers [11].

Under most circumstances, when a law enforcement officer detains an individual, the curtailment of the person's physical freedom is incidental. When the loss of physical liberty is weighed against society's need to maintain an orderly society, the reduction in physical freedom does not usually rise to the level of a violation of procedural due process [12]. However, when a police officer demands that an individual engages in sexual intercourse or face possible incarceration, then a person's procedural due process rights are violated because a police officer is an agent for the state [13].

In one sense, it does not matter whether the individual who is providing sexual favors to the law enforcement officer is a legal adult or minor child. In such instances, the law enforcement officer has significantly violated the liberty interest and physical freedom interest of the individual [14].

Furthermore, it does matter whether the law enforcement officer is on or off duty [15]. A person is usually unaware of the duty status of a police officer. The only thing that matters to an individual is that a police officer is detaining him or her. The individual may honestly believe that if he or she does not fully cooperate with the officer, then that person will probably be arrested, and charged with some offense, including possibly resisting arrest. It should be remembered that police officers can constitutionally engage in low-level trickery with the general population, particularly when the officer has reasonable suspicion or probable cause [9].

With that said, a police officer does have the constitutional right to solicit an individual for sexual intercourse provided that the person is not under duress [15]. If the individual decides to reject the sexual advances of a law enforcement officer but is instructed by the officer that his or her rejection may result in being charged with a specific crime or possible incarceration, the individual may capitulate to the officer's proposal, thereby avoiding arrest or incarceration.

An off-duty law enforcement officer has a constitutional right as a private individual to solicit sexual intercourse with a consenting adult [13]. This right is abrogated when the person in question is a minor child because a minor child does not have the legal capacity by law to consent to sexual intercourse [14]. However, if an off-duty police officer exploits his or her power as an officer of the law to entrap an adult or minor child into engaging in sexual intercourse, such behavior is an abuse of police power. It should and ought to be deemed illegal [14].

Finally, there is the issue of enhanced penalties to discuss. Police officers can make reasonable mistakes or even unreasonable but honest mistakes. However, when a law enforcement officer initiates an offer of sexual intercourse with an individual who is the subject of Terry stop, the officer is neither making a reasonable mistake nor an unreasonable but honest mistake $[16,17]$. The law enforcement officer is intentionally soliciting an individual to engage in sexual intercourse, where the threat of arrest and imprisonment is usually imminent. Thus, an enhanced penalty is justified on procedural due process grounds because the police officer is engaging is a voluntary and intentional act that significantly limits the liberty and physical freedom interests of an individual.

Thus, based on procedural due process, the Model Penal Code should include an enhanced penalty or offense when a law enforcement officer engages in sexual conduct while on duty with any individual, including a child, or is involved in sexual violence of any kind whether on or off duty. 


\section{Substantive Due Process Mandates Inclusion}

In this case, the issue is whether substantive due process mandates the inclusion into the MPC of an enhanced penalty or offense when a law enforcement officer engages in sexual conduct while on duty with any individual, including a child, or is involved in sexual violence of any kind whether on or off duty. In United States constitutional law, substantive due process is a principle allowing courts to protect individual rights deemed fundamental from government interference [17].

The question is whether such police behavior violates a right that is both fundamental and personal or economic and social. Fundamental and personal rights include due process, speech, religion, privacy, marriage, interstate and intrastate travel, equality, assemble, to bear arms [18]. In such cases, there must be a compelling state interest that supersedes a person's fundamental and personal rights [19]. In contrast, a right is not a fundamental and personal right when the right is economic or social [19]. According to the Supreme Court, in such cases, there need only be a rational relationship between a law enforcement officer's actions and legitimate government purpose [20].

Here, when a police officer exploits his or her position as an officer of the law to demand sexual intercourse from an individual, the law enforcement officer is violating an individual's fundamental and personal procreation right because sexual intercourse can result in the birth of an unwanted but innocent child [21]. Thus, strict scrutiny can be used to conclude that such behavior by a law enforcement officer violates a person's substantive due process rights [21].

As for an individual's economic and social rights, there is the societal stigma of being forced to engage in sexual intercourse against one's will [22]. Other people could construe such behavior as an indication that an individual possesses a weak moral character, resulting in the possible loss of employment or social ostracization [22]. Thus, there is no apparent rational relationship between the law enforcement officer's behavior and a legitimate government purpose. The government, whether it is a state or local government, has no logical reason for subjecting an individual to societal condemnation merely because one of its officers demands sexual intercourse in exchange for not being subject to the workings of the legal system.

Thus, based on substantive due process, the Model Penal Code should include an enhanced penalty or offense when a law enforcement officer engages in sexual conduct while on duty with any individual, including a child, or is involved in sexual violence of any kind whether on or off duty.

\section{Equal Protection Warrants Inclusion}

Similar to what has been addressed above, the issue is whether equal protection warrants the inclusion into the MPC of an enhanced penalty or offense when a law enforcement officer engages in sexual conduct while on duty with any individual, including a child, or is involved in sexual violence of any kind whether on or off duty. In United States constitutional law, equal protection is guaranteed under the Fourteenth Amendment, whereby a state must treat an individual or class of individuals the same as it treats other persons or classes in like circumstances [23].

The Equal Protection Clause of the Fourteenth Amendment deals with state action [24]. State action is any action that is taken by a state government or its agents that intrude on an individual's civil rights where the correction of the state action requires the enforcement of judicial action [24]. Equal protection entails that the state action creates a classification, such as men vs. women, young vs. old, resident vs. non-resident, etc. [25]. Here, the classification separates young adult women and female minor children who are the victims of the abuse of police power versus the rest of the population who are not the victims of a violation of police power.

The prosecutor wanted to introduce evidence from numerous studies indicating that law enforcement officers are prone to sexually abusing minors and young women. The reason that the prosecutors may have desired to add these statistical studies is to demonstrate to the court that the classification above has merit [26]. Police officers are in a position of trust and authority over societal members, including women and girls, and any sexual engagement between the officer and a defendant constituted probable cause for sexual assault. In contrast, defense counsel argued that the statistics should not be admitted into evidence because the MPC governs the jurisdiction. This argument misses the mark. Although the MPC does not specify that sexual intercourse between a law enforcement officer and a woman or female minor child is an enhanced criminal act, the MPC must yield to the Equal Protection Clause of the Fourteenth Amendment because of the Supremacy Clause [27]. In other words, the MPC must relinquish its authority to the constitutionally guaranteed right in the Fourteenth Amendment of equal protection of all members of society.

When a law enforcement officer acts in furtherance of his or her duties as a police officer and demands sexual intercourse from young women and female minor children, there is an apparent discriminatory effect. In this instance, the impact of demanding sexual favors from a young woman or female minor child requires the use of intermediate scrutiny and the rational relation test because the classification deals with both gender and age respectively [28].

Here, a law enforcement officer is abusing his or her police power by pressuring a young woman or female minor child to engage in sexual intercourse against their will. This behavior by an officer of the law cannot be justified or even excused by the existence of a legitimate government purpose. The act is an abuse of the duties of a police officer under the Equal Protection Clause of the Fourteenth Amendment [13].

However, as argued previously, if a police offer is off duty, no such violation of equal protection occurs unless the law enforcement officer is exploiting the powers of his or her office to extract sexual favors from young women or female 
minor children [13]. A similar equal protection argument is valid if a law enforcement officer is involved in sexual violence, such as rape or deviate sexual behavior, whether or not the police officer is on or off duty [25].

Thus, based on equal protection, the laws of the state should be modified to include an enhanced penalty or offense when a law enforcement officer engages in sexual conduct while on duty with any individual, including a child, or is involved in sexual violence of any kind whether on or off duty.

\section{The Moral Authority of the MPC Demands Inclusion}

At issue is whether the moral authority of the MPC demands the inclusion into the MPC of an enhanced penalty or offense when a law enforcement officer engages in sexual conduct while on duty with any individual, including a child, or is involved in sexual violence of any kind whether on or off duty. Moral authority is an authority that is premised on principles, or fundamental truths, that are independent of written or current laws. In other words, moral authority is predicated on the existence of and adherence to truth [29]. This means that the Model Penal Code is a written expression of the moral authority of society as specified by the American Legal Institute.

The answer to the question can be decided conclusively if the Model Penal Code possesses moral authority. An essential feature of the MPC is that any action not explicitly outlawed is legal. This concept adheres to the proverb, "That which is not forbidden is allowed" as opposed to "That which is not allowed is prohibited" $[30,31]$. These notions form the basis of the defense counsel's argument.

The hidden agenda of the issue, as specified in this section of this memorandum, is the same problem that the State of Idaho faced in 1971 when it adopted the entire Model Code. Three months after its adoption, the Idaho state legislature repealed the action in 1972 because the MPC utterly failed to regulate basic human morality, such as sodomy, adultery, and fornication as crimes [32].

Although the Supreme Court legalized sodomy in Lawrence v. Texas, the fact that the nation has traditionally viewed sodomy, adultery, and fornication as morally objectionable undercuts the moral authority of the Model Penal Code [33]. If anything is morally correct about the MPC, it is that the underlying morality of the Code is highly permissive. In other words, the moral authority of the MPC is inconsistent with Judeo-Christian beliefs that have dominated American society for over 200 years [34]. This is not to say that there is no moral authority implicit in the Model Penal Code. Instead, what is being argued is that the moral authority of the MPC is either non-existent or is sufficiently permissive to be ineffective or inconsistent with the moral compass of the nation.

Thus, based on the lack of moral authority of the MPC, the Model Penal Code should include an enhanced penalty or offense when a law enforcement officer engages in sexual conduct while on duty with any individual, including a child, or is involved in sexual violence of any kind whether on or off duty. The Model Penal Code should be enhanced not because of the moral authority of the Model Penal Code, but rather because of the other constitutional considerations discussed above.

\section{Public Welfare Considerations Require Inclusion}

In this instance, the issue is whether public welfare considerations require the inclusion into the MPC of an enhanced penalty or offense when a law enforcement officer engages in sexual conduct while on duty with any individual, including a child, or is involved in sexual violence of any kind, whether on or off duty. The public welfare or public policy is the benefit or advantage experienced by society as a whole regarding a class of issues that is consistent with law and institutional customs $[35,36]$.

Public welfare, more commonly known as public policy, is the principled guide to actions taken by the executive branch of a state $[35,36]$. Because law enforcement officers report to the executive branch of state government, public policy considerations regarding this issue are entirely appropriate to analyze. Public policy is healthy when it solves problems efficiently and effectively by serving justice and supporting governmental institutions through encouraging active citizenship [35, 36]. Public policy is weak or non-existent when it does not address pressing societal issues, or it solves problems inefficiently or ineffectively, not serving justice, supporting governmental institutions, or promoting active citizenship [35, 36].

Here, a law enforcement officer propositioned a 15 -year old girl to engage in sexual intercourse after the officer caught her experimenting with marijuana. The officer demanded that the girl agree to have sex in exchange for not arresting her, possibly resulting in Mona being sent to prison for several years. The question here is whether the police officer's behavior is sufficiently egregious to warrant changing the penalty from a misdemeanor to a felony with an enhanced penalty.

Suppose that the MPC does not change, and the crime of sexual assault remains a misdemeanor. What is the message that that is being communicated to law enforcement officers? In making sexual assault a misdemeanor rather than a felony, the message of the MPC is that sexual assault is not necessarily a serious crime. The court may suspend sexual assault cases against law enforcement officers, where the result is no prison time $[3,13]$. The result could very well be a slow and steady disintegration of respect for law and order by a citizenry that are victims of such police officer action [37].

In contrast, if the crime is made a felony with enhanced punishment, then society is proclaiming to its citizens, particularly to law enforcement officers, that such behavior will not be tolerated [37]. The result will probably be a 
renewed respect for the laws of the state, which may, in turn, lead to reduced crime, at least crime perpetrated by police officers [37].

Thus, based on public policy considerations, the Model Penal Code should include an enhanced penalty or offense when a law enforcement officer engages in sexual conduct while on duty with any individual, including a child, or is involved in sexual violence of any kind whether on or off duty.

\section{Conclusion}

Therefore, the Model Penal Code should explicitly make it an enhanced penalty or offense when a law enforcement officer engages in sexual conduct while on duty with any individual, including a child, or is involved in sexual violence of any kind, whether on or off duty.

\section{References}

[1] Paulsen, M. G., \& Kadish, S. H. (1964, February). Criminal Law and Its Processes. Harvard Law Review, 77 (4), 5. doi: $10.2307 / 1339153$.

[2] Upcounsel Staff. (n.d.). The Model Penal Code (MPC). Upcounsel. https://www.upcounsel.com/lectl-model-penalcode-mpc-criminal-law-basics.

[3] Model Penal Code § 213 (Official Draft and Explanatory Notes 1985).

[4] National Association of Criminal Defense Lawyers. (2016, March 02). NACDL Comments on Model Penal Code: Sexual assault and related offenses Preliminary Draft No. 6 http://www.prosecutorintegrity.org/wpcontent/uploads/2016/03/NACDL-Comments-Draft-6-MPCSexual-Assault.pdf.

[5] American Law Institute. (n.d.). Model Penal Code: Sexual assault and related offenses. American Law Institute. https://www.ali.org/projects/show/sexual-assault-and-relatedoffenses/.

[6] Mathews v. Eldridge, 424 U.S. 319, 332 (1976).

[7] United States v. Sokolow, 490 U.S. 1, 7 (1989).

[8] Carroll v. United States, 267 U.S. 132, 162 (1925).

[9] Frazier v. Cupp, 394 U.S. 731 (1969).

[10] Garner, B. A. [ed.]. (2004). Black's Law Dictionary (8th ed.). St. Paul, MN: West \& Thompson Publishers.

[11] American Civil Liberties Union of Illinois v. Alvarez, 679 F. 3d 583 (7th Cir. 2012).

[12] United States v. Mendenhall, 446 U.S. 544 (1980).

[13] Rogers v. City of Little Rock, Arkansas, 152 F. 3d 790 (8th Cir. 1988).

[14] United States v. Caudill, 709 F. 3d 444 (5th Cir. 2013).

[15] Sylvester v. Fogley, 465 F. 3d 851 (8th Cir. 2006).
[16] Terry v. Ohio, 392 U.S. 1 (1968).

[17] U.S. Const. amend. V and U.S. Const. amend. XIV $\S 1$.

[18] Shneebaum, S. M. (1998). Human rights in the United States: The role of lawyers. Washington and Lee Law Review. 55 (3). https://scholarlycommons.law.wlu.edu/wlulr/vol55/iss3/6.

[19] Leckie, S., \& Gallanger, A. (2006). Economic, Social and Cultural Rights: A Legal Resource Guide. Philadelphia, PA: University of Pennsylvania Press.

[20] Massachusetts Bd. of Retirement v. Murgia, 427 U.S. 207 (1976).

[21] Roe v. Wade, 410 U.S. 113 (1973).

[22] Kogan, S. M. (2004). Disclosing Unwanted Sexual Experiences: Results from a National Sample of Adolescent Women. Child Abuse \& Neglect, 18 (2), 19. doi: 10.1016/j.chiabu.2003.09.014.

[23] Bolling v. Sharpe, 347 U.S. 497 (1954).

[24] Snyder, B. R. (1990, July). Private motivation state action and the allocation of responsibility for Fourteenth Amendment violations. Cornell Law Review, 75 (5), 42. http://scholarship.law.cornell.edu/clr/vol75/iss5/3.

[25] J. E. B. v. Alabama ex rel. T. B., 511 U.S. 127 (1994).

[26] Bazemore v. Friday, 478 U.S. 385, 400 (1986).

[27] U.S. Const. Art. VI, Cl. 2.

[28] United States v. Virginia, 518 U.S. 515 (1996).

[29] Robinson, P. H. (2008). Distributive principles of criminal law: Who should be punished how much? Oxford, UK: Oxford University Press.

[30] Andenas, M., \& Fairgrieve, D. [eds.] (2000). Liber Amicorum in honor of Lord Slynn of Hadley: Judicial Review in International Perspective. The Hague, The Netherlands: Kluwer Law International.

[31] White, T. H. (1938). The Sword in the Stone (book 1 of The Once and Future King). Cork, Ireland: Collins Press.

[32] Eskridge Jr., W. N. (2008). Dishonorable passions: Sodomy laws in America. New York: Penguin Group.

[33] Lawrence v. Texas, 539 U.S. 558 (2003).

[34] Bowers v. Hardwick, 478 U.S. 186 (1986).

[35] Norwich University Online. (2020, October 26). Characteristics of successful public policy. Norwich University. https://online.norwich.edu/academicprograms/resources/characteristics-successful-public-policy.

[36] Kilpatrick, D. (2000). Definitions of public policy and law. National Violence Against Women Prevention Research Center: Medical University of South Carolina. https://mainwebv.musc.edu/vawprevention/policy/definition.shtml.

[37] Ramphele, M. (n.d.). Social disintegration in the black community - Implications for transformation. Nelson Mandela Centre of Memory. https://www.nelsonmandela.org/omalley/index.php/site/q/03lv 01538/04lv01584/05lv01585.htm. 